\title{
Does Egalitarian Democracy Boost Environmental Sustainability? An Empirical Test, 1970-2017
}

\author{
Amber Roeland ${ }^{1} \&$ Indra de Soysa ${ }^{2}$ \\ ${ }^{1}$ Dept. of Politics, University of Ghent, Belgium \\ ${ }^{2}$ Dept. of Politics \& Sociology, Norwegian University of Science \& Technology (NTNU), Trondheim, Norway \\ Correspondence: Indra de Soysa. Dept. of Politics \& Sociology, Norwegian University of Science \& Technology \\ (NTNU), 7491 Trondheim, Norway. E-mail: indra.de.soysa@ntnu.no
}

Received: January 26, 2021

Accepted: March 12, 2021

Online Published: March 14, 2021

doi:10.5539/jsd.v14n2p163

URL: https://doi.org/10.5539/jsd.v14n2p163

\begin{abstract}
Many argue that the twin problems of poverty and environmental degradation are best addressed by adopting greater egalitarian processes of governance. Greater egalitarian societies apparently contain the required social trust and consensus for making hard choices and tradeoffs for achieving environmental gains. We employ novel data on egalitarian democracy, which measure the equal access of the poor to political power and societal resources, and data covering weak and strong sustainability measured by the "adjusted net savings" and several indicators of atmospheric pollution. The results suggest that greater egalitarian governance reduces weak sustainability and increases the intensity of climate-harming pollution. Regardless of democracy, other measures of social equity, such as the GINI and equal access to health and political resources, increase, not decrease, atmospheric pollution. These results are robust to estimating procedure, several alternative models, and data. While liberté, egalité and fraternité should be pursued for their own intrinsic value, meeting urgent challenges from global warming may require more targeted solutions.
\end{abstract}

The twin defining challenges of the twenty-first century are overcoming poverty and managing climate change. If we fail one, we fail the other.

\section{Nicholas Stern (2015). Why Are We Waiting: The Logic, Urgency, and Promise of Tackling} Climate Change. London. The MIT Press.

The world's ability to manage global crises such as climate change depends on our ability to achieve broad-based economic prosperity and stability.

\section{James K. Galbraith (2019). "The Next Great Transformation" Project Syndicate} (November 08). Online periodical.

Policies that squeezed the poor while allowing the rich to continue to produce much higher levels of emissions would be unlikely to gain widespread support.

Richard Wilkinson and Kate Pickett (2009). The Spirit Level: Why More Equal Societies Almost Always Do Better. London: Allen Lane. Pg. 218.

\section{Introduction}

As the statements quoted above suggest, two interrelated problems pose challenges for policymakers-how might we achieve environmental sustainability and reduce between- and within-country inequality? (OECD, 2015; Griggs et al., 2013; Dryzek et al., 2011). In essence, finding trade-offs that address the economic concerns of the poor without harming the planet is possibly the "golden calf" of policy, first addressed decades ago by the World Commission on Environment and Development (WCED, 1987). Since then, environmental concerns subsumed under the term "sustainable development" is part of mainstream politics, and one that has recently begun to split people along "class" lines, at least within the industrialized world, where people facing economic insecurity seem to downgrade environmental concerns (Dryzek, 1997; Inglehart and Norris, 2016). Consider the populistic backlash seen across the rich world, blamed mostly on the discontent of the have-nots rebelling against so-called "establishment elites" accused of foisting a climate "hoax" on ordinary people (Worland, 2019). Populistic leaders in poor countries, too, such as in Brazil and India, are abrogating environmental agreements and treaties in the 
name of economic growth, despite the fact that countries across the world have signed up to the United Nations' 17 sustainable development goals (Harvey, 2019). With rising income inequality within the rich world, the left blames corporate capitalism for "environmental injustice," where poverty, inequality and environmental harm are seen as a single conundrum (Stiglitz, 2019b). By intimation, the environmental crisis is blamed on the rich and powerful who pollute at the expense of the powerless (Bell, 2014; Wilkinson and Pickett, 2009). Thus, one strong prescription for environmental sustainability is greater egalitarianism, where political leaders govern with the broad collectivity in mind, thereby gaining legitimacy for the consensus required for achieving environmental policy goals. We address this question empirically by using novel data on egalitarian governance and several measures of "weak" and "strong" sustainability measured as adjusted net savings and the intensity of atmospheric pollution.

We use novel governance data for roughly 170 countries covering the years 1970-2017 capturing greater egalitarian democracy from the Varieties of Democracy (VDEM) project. Our sustainability measures capture notions of "weak" sustainability, as measured by the World Bank's adjusted net savings (ANS) as a share of Gross National Income (GNI) and $\mathrm{CO}_{2}$ damage measured as $\mathrm{CO}_{2}$ emissions per GDP produced, as well as "strong" sustainability measured as climate-harming emissions, namely, Carbon Dioxide $\left(\mathrm{CO}_{2}\right)$ emissions per capita and total greenhouse gas emissions (GHGs) per capita. The results are easily summarized. Egalitarian democracy reduces both weak and strong sustainability. The results suggest that democracies that govern with greater inclusivity in terms of access to political rights and liberties and where there is equality of power resources between the poor and the rich reduce, not increase, environmental sustainability. It seems that trying to achieve broad-based support for climate policies by offering people more consumption opportunity is a policy conundrum that does not ease with greater egalitarian political and economic processes. Increasing wealth increases weak sustainability, but both greater democracy and wealth per capita increase the intensity of greenhouse gas pollution. Inequality, measured by the GINI and inequality of access to health, associate with better environmental outcomes, not worse ones. The results simply do not support the view that pro-poor governance also produce environmental gains. The results are robust to several estimating strategies, alternative models, data, and sample sizes.

\section{Theory}

Questions of equity, particularly intergenerational equity, and the question of fair distribution of the burdens of the transition to a low carbon future is at the heart of stalled environmental agreements (Stern, 2015). For reaching the Intergovernmental Panel on Climate Change's (IPCC) target of achieving no more than a $2^{\circ} \mathrm{C}$ increase in temperature by century's end, there have to be drastic cuts in $\mathrm{CO}_{2}$ emissions across the globe. The experts suggest that average global greenhouse gases (GHGs) be limited to 2 metric tons per person per annum by 2050 essentially an 80\% reduction from 1990 levels (Stern 2015). According to the United Nations Environment Program (UNEP), "total GHG emissions, including from land-use change, reached a record high of $55.3 \mathrm{GtCO} \mathrm{e}$ in 2018. There is no sign of GHG emissions peaking in the next few years; every year of postponed peaking means that deeper and faster cuts will be required. By 2030, emissions would need to be 25 per cent and 55 per cent lower than in 2018 to put the world on the least-cost pathway to limiting global warming to below $2{ }^{\circ} \mathrm{C}$ and $1.5^{\circ} \mathrm{C}$ respectively" (UNEP, 2019). With the poor countries now rapidly increasing their share of global emissions, reducing poverty without increasing per capita output of GHGs requires a rapid transition to low carbon solutions to avoid environmental disaster. Can egalitarian government increase the chance of such a transition?

Currently, there is little to be optimistic about a green transition given the political climate of hostility towards climate change mitigating policies across the world. The question of potential solutions to these crises have spawned several distinct discourses (Dryzek, 1997). These discourses might be considered the "software" that generates the "institutional hardware" for engaging people and addressing the problems. The discourses are also political anchors for policymakers to bargain over policy and design politically-feasible solutions. Indeed, such discourses might also be thought of as "ideas" around which people might find consensus within and across states, so as to achieve the best, most consensual bargains for designing effective environmental regimes (Conca and Dabelko, 1998). The problems that environmental questions pose for policy are described by some as "diabolical" because of the very complex, all-encompassing and rapidly moving change with which policymakers have failed to keep pace (Steffen, 2011). Moreover, the cross-cutting issues that embroil man and nature, economy and society, citizens and states, present and future generation, diverging interests between states, not to mention problems of cognition and complexity, pose enormous challenges for governance (Jamieson, 2011). There are clearly no easy solutions, particularly when one considers questions of environmental justice based on who has benefited from creating environmental harm and who now pays the costs of the consequences, while at the same time reducing, or even reversing, environmental harm.

The governance of a country (state) takes many forms, usually shaped by the formal and informal institutions, or 
"rules of the game" that shape human interaction (Acemoglu and Robinson, 2012; Ostrom, 2005; North et al., 2013). According to Acemoglu and Robinson (2012), inclusive institutions, especially those determined by centralized state power, lead to inclusive economic institutions, which form the rules that determine productivityenhancing technological change, which in turn, determines how states succeed economically. When people are unhindered from making investments and reaping the benefits of their labor, then economies progress (grow) because capricious elites are not in a position to block you. Contrarily, extractive institutions allow elites to seek rents by establishing monopolies, blocking technological change, and maintaining the status quo without making the necessary reforms that would allow a society to move out of the vicious cycle of elite extraction, which keeps economic progress constrained. In the simplest formulation, the issue of governance and development might not be simply a question of whether democracy is preferable to dictatorship but the balance of inclusive/extractive institutional rules that minimize rent-seeking.

The politics of the earth has spawned a discourse suggesting that democracy is better than autocracy (dictatorship) for achieving greater sustainable growth and a cleaner environment (Dryzek, 1997). An open democratic society would allow people to demand a more climate friendly, sustainable policy path. Many argue that elections and other instruments available to a democratic public will control capricious elites, who will otherwise abuse nature by plundering for profit. New parties devoted to "green politics" and climate-friendly civil society groups will arise to lobby governments. Such groups will also directly lobby and influence powerful economic forces, such as corporations, unions, and consumers in climate-friendly ways (Jordan et al., 2003). Many observers argue that inclusive policymaking might gain more legitimacy and thereby be more effective (Niemeyer, 2013). A polity can be called inclusive when all the individuals that are affected by the decision have the opportunity to deliberate and provide input to the decision-making process. The more inclusive a democracy is, the better environmental outcomes it produces. It is argued that climate change normally is easily crowded out by the prevailing character of the political debate, but that deliberation may make complex issues less confusing and solutions more tangible. The act of deliberation itself activates a commitment to environmental thinking, perhaps even sympathy for future generations and willingness to compromise on current solutions for achieving shared environmental goals.

Others argue that democratic publics are often wrong and produce irrational outcomes because of problems of aggregating preferences and because of rational ignorance among the mass of voters about complex problem (Schumpeter, 1943; Achen and Bartels, 2017; Caplan, 2008). Many studies show how voters choose self-defeating policies when voting prospectively, even on relatively simple policies chosen in direct popular votes, and how the mass of voters generally cannot discern bad policy retrospectively, often using simple rule-of-thumb grounds for choosing political candidates (Achen and Bartels, 2017). Contrary to the folk theory of democracy, democratic publics may demand broad-based economic development over environmental factors, demand higher consumption regardless of pollution, and generally fail to act on preventing environmental degradation, particularly if one's actions are likely to be detrimental to others, such as future generations or strangers. Democratic leaders, particularly in the developing world, intent on political survival, are likely to promise greater access to consumption, higher growth, more public goods in the form of infrastructure-roads, urbanization, agricultural extension, hydroelectric dams, and access to mining etc. Given the fact that the environment is a "commons", each individual person's incentive to contribute to mitigating the harm relative to the payoff obtained from free-riding on others, make environmental policymaking deeply vulnerable to the "tragedy of the commons" (Hardin, 1993).

The experience with "new environmental policy initiatives," which incentivize corporations and private civil society organizations to act voluntarily have had very mixed effects, with many of these initiatives occurring outside of truly democratic arenas. Even global civil society initiatives often work as mechanisms of "green washing" rather than delivering better environmental performance, often even harming poor people on the ground (Peluso, 2003). Thus, the ways in which more inclusive governance might affect climate-friendly policy, or even sustainable development, is highly mixed and indeterminate (Ward, 2008; Midlarsky, 2001).

The empirical evidence for a simple regime type effect on desirable environmental governance is mixed, as is the question of what type of regime, or what types of democratic institutional rules make countries either leaders or laggards on climate-friendly economic policies, is theoretically and empirically indeterminate (Christoff and Eckersley, 2011; de Soysa et al., 2009; Li and Reuveny, 2006; Congleton, 2002). The recent performance of the industrialized democracies on failing to keep their commitments on greenhouse gas emissions, as well as the populistic attacks on climate change treaties and policies, exemplified most recently by the United States and Brazil, stand in stark contrast with China's willingness to lead on cutting fossil fuel use and adopting more climate friendly politics (Schreurs, 2011). As some suggest, perhaps there are "eco-dictatorships" that follow climatefriendly policies out of necessity or due to happenstance (Wurster, 2013).

We suggest that rather than examining the ideal types of political governance, the issue might be better addressed 
from the point of view of the economic outcomes and societal determinants associated with one or another style of political governance. As Christoff and Eckersley (2011) have suggested, among the industrialized democracies, at least, the more consensual form of democracy may matter more than the more liberal form of democracy. Yet, as they note themselves, the United Kingdom has done even better than Germany on climate-friendly policies and sustainability. Nor is it clear that democracies with stronger, more active labor unions are better at climate-friendly policies, given that unions have a strong incentive to protect polluting industry, such as coal and oil, resisting lesspolluting, labor-saving technological change (Bernauer and Kouby, 2009). Large corporation, particularly those dominating the hydrocarbon and mining industries, also lobby governments in ways that allow them to escape tight regulation, with much left up to voluntary compliance rules that are mostly side-stepped (Wenar, 2016; Collier, 2018). Thus, all democracies are likely to be victim of rent-seeking to varying degrees, with the poor world, where institutions are weak and corruption greater, most likely to suffer unsustainable paths of economic growth and development (Collier, 2010; Dietz et al., 2007; Achen and Bartels, 2017).

Recently, many have begun to look deeper into the political-economy bases of neo-liberal economic democracy, treating the so-called failures of capitalism and the discontent directed at it as arising from antipathy towards rising inequality across the world (Milanovic, 2016; Stiglitz, 2019a; Galbraith, 2019). Stiglitz (2019a), like Galbraith (2019) quoted above, suggest that resistance to climate change mitigation arises from "unfair" economic development, the so called "backlash" against globalization and elite-led democracy. These scholars argue, much like the debate about democracy and sustainability, that neo-liberal capitalism is susceptible to being captured by special interests. According to Stiglitz (2019a: online),

If the 2008 financial crisis failed to make us realize that unfettered markets don't work, the climate crisis certainly should: neoliberalism will literally bring an end to our civilization. But it is also clear that demagogues who would have us turn our back on science and tolerance will only make matters worse.

Indeed, there is much to the idea that a broad-based democracy, where ordinary people have an equal chance of influencing the system, and where people think that government works for most people fairly, and where they distribute resources through public goods more evenly, then sustainable economic policies are likelier. Apparently, the "Donald Trumps" and "Jair Bolsanaros" are created by discontent with political elites who fail to deliver. (Note 1) As two bold advocates for more equal societies cited at the outset suggest, equal societies will be more consensual when it comes to pursuing common goals, whereas "squeezing the poor" leads to disarray (Wilkinson and Pickett, 2009). In other words, more egalitarian policies and outcomes are likely to build broad-based social consensus around the public good of mitigating climate change and reducing environmental damage (Farzin and Bond, 2006). Such pro-poor governance, whether by democracies or autocrats, is also thought to be relevant for developing country (LDC) growth and sustainability, leading to both economic development and better environmental outcomes (Dollar and Collier, 2001).

Just as in the democracy and environment question, there is rather mixed evidence on the question of income inequality and environmental quality (Scruggs, 1998; Bernauer and Kouby, 2009; Clement and Meunie, 2010). Scruggs (1998) suggests that it is impossible to make generalizations about the effect of income distribution on environmental degradation without knowing more about preferences. Scruggs shows that equality may or may not be necessary to minimize degradation. It might even be the case that more inequality may result in lower degradation, simply because the poor will have less access to consumption opportunities. The reasons for this are twofold, first of all, preferences for environmental degradation are likely to cut across traditional income and power groups, where the rich may demand better environmental policies regardless of the living conditions of the mass of poor. Second, choices about environmental degradation are made at many levels of society, with a variety of actors operating under a variety of institutional conditions (Scruggs 1998: 259-275). Moreover, inequality across classes might not have the same effects on politics and economics as inequality across groups, such as gender, ethnicity, race, and religion (Stewart et al., 2005). Typically, such measures as the GINI coefficient are fairly poor at capturing other dimensions of exclusion, such as outcomes measured by health and educational levels etc., or as some critics suggest is "an 'inequality debate' that fixates on the finances alone" (Deaton and Case, 2020). Thus, we focus on a broader measure of egalitarian governance by examining a measure of "egalitarian democracy" on weak and strong sustainability using the novel Varieties of Democracy data project's measure defined as,

egalitarian democracy as a regime that provides de facto protection of rights and freedoms equally across the population, distributes resources in a way that enables meaningful political participation for all citizens and fosters an environment in which all individuals and social groups can influence political and governing processes (Sigman and Lindberg, 2019). (Note 2) 
We also use traditional measures of inequality, net of the level of democracy, for comparison with previous studies. Considering the discussions above on the indeterminacy of democracy and the environment as well as inequality and the environment, we test the following hypothesis:

\section{H1: Stronger egalitarian governance increases sustainability and reduces climate-degradation}

Measuring sustainability

The question of sustainable development and environmental security are complex and multifaceted (Atkinson et al., 2007; Pearce and Atkinson, 1993). Like most, we follow the definition of the Brundtland Report (WCED 1987: 43) which defines sustainability as "development that meets the needs of the present without compromising the ability of future generations to meet their own needs" and subsequent attempts at trying to measure sustainability objectively (Hamilton, 2000; Atkinson et al., 1999). Sustainable development represents a process of improvement of the human and environmental condition, or a process by which all forms of "capital"-human, physical, and natural - are non-declining. Sustainable development essentially means balancing the tradeoffs that would ensure current and future "wellbeing" with the least possible harm to the planet and its resources, or when possible even producing environmental improvement. For many, the concept provides a framework for considering economic efficiency, not just by how much is produced but also by subtracting the harm to natural capital, both in terms of resource loss and the pollution of the atmosphere (Lafferty and Meadowcroft, 1996). As Stern (2015) has shown convincingly, there are many options for reducing global warming by adopting a host of mitigating policy paths. As he (2015: 80) writes:

The transition to low-carbon, more resource-efficient growth can also be one of greater inclusiveness and stronger communities, for example by fostering local access to basic needs, such as water and energy. It can deliver opportunities for growth creation in rural and forested areas, by monetizing opportunities for reducing emissions from deforestation or to preserve biodiversity...the potential from these low-carbon paths is immense.

The core debates about sustainable development is therefore about the balance between current consumption and production in relation to the future. This balance might be struck along the two dimensions of "weak" versus "strong" sustainability. Weak sustainability does not give a special place to the environment, but it is the overall portfolio of wealth bequeathed to future generations that matter. In other words, future generations can have some balance of forests and universities that increase their wellbeing. Strong sustainability, on the other hand, puts the environment at the center, where environmental harm produced is what counts and not the efficiency with which wealth is produced (Atkinson et al., 2007). In the above example, building universities would be considered an environmental harm regardless of the value of universities to society. At a minimum, rather than rely purely on GDP as a measure of wellbeing, or even physical capital savings as a measure of future wellbeing, green accounting allows us to measure the performance of countries over time in terms of the balance between environmentallyefficient production and environmental profligacy. We, thus, use the World Bank's "Adjusted Net Savings" as our primary measure of weak sustainability, following many others (de Soysa and Neumayer, 2005; Hess, 2010; Qasim and Grimes, 2018). We believe, like others, that climate policies that do not benefit society, particularly the poorer segments, are morally indefensible and perhaps also counterproductive due to political backlash (Stern, 2015). We examine the details of the measurement of these data in detail below.

\section{Data \& Method}

Our primary measure of sustainability is Adjusted Net Savings as a share of GNI taken from the World Bank's World Development Indicators online database. (Note 3) According to the World Bank,

ANS is equal to the net national savings plus education expenditure, minus energy depletion, mineral depletion, net forest depletion, and carbon dioxide and particulate emissions damage ... ANS measures gross national savings, adjusted for gains (spending on education) and losses (consumption of fixed capital, depletion of subsoil assets and forests, pollution damages). When ANS is negative, it may indicate that wealth is being run down; when ANS is positive, it may indicate that wealth is growing (World Bank, 2020).

Thus,

ANS $=$ savings + education $\&$ health spending - energy depletion - mineral depletion - forest depletion $-\mathrm{CO}_{2}$ damage - particulate emissions damage / GDP

Where savings $=$ GDP - consumption (public \& private) - govt. debt + exports (assuming an open economy). 
Since a society's savings essentially embody investment towards the future, any savings accumulated from stripping mother nature, polluting the atmosphere, and ensuring future sustainability of a population by withholding public goods, such as education, is clearly an unsustainable path, or in other words, bad investment in the future. (Note 4) Naturally, any such broad-based measure has many gaps. For example, education spending does not capture the quality of education. Natural resource depletion does not capture soil degradation, diminishing fish stocks, or the depletion and degradation of water quality. Additionally, $\mathrm{CO}_{2}$ and particulate emissions are not the only sources of pollution harmful to human health. Regardless, any society not even meeting these standards are likely to be in big trouble. At a minimum, it provides a useful guide for policymakers for judging their performance over time.

In addition to ANS, we also consider pure environmental harm in terms of $\mathrm{CO}_{2}$ damage separately. $\mathrm{CO}_{2}$ damage is defined as:

the cost of damage due to carbon dioxide emissions from fossil fuel use and the manufacture of cement, estimated to be US $\$ 30$ per ton of $\mathrm{CO}_{2}$ (the unit damage in 2014 US dollars for $\mathrm{CO} 2$ emitted in 2015) times the number of tons of $\mathrm{CO}_{2}$ emitted" (World Bank 2020).

Thus, $\mathrm{CO}_{2}$ damage is given a dollar value so that emissions can be assessed against the value of GDP produced. Since the price is the same for all countries, it is the $\mathrm{CO}_{2}$ pollution in tonnage that would vary between and within countries. Given that pollution is taken in terms of production, this measure too is a measure of weak sustainability since the denominator, GDP will determine the degree of pollution. In other words, this measure is an indicator of efficiency rather than pollution intensity.

Next, we use two measures of "strong" sustainability indicated by both total $\mathrm{CO}_{2}$ produced per capita and total greenhouse gasses produced on a per capita basis. These two measures are indicators of environmental harm, regardless of economic efficiency. According to the World Bank,

the total greenhouse gas emissions are composed of $\mathrm{CO} 2$ totals excluding short-cycle biomass burning (such as agricultural waste burning and Savannah burning) but including other biomass burning (such as forest fires, post-burn decay, peat fires and decay of drained peatlands), all anthropogenic CH4 sources, N2O sources and F-gases (HFCs, PFCs and SF6) (World Bank 2020).

These two strong sustainability measures indicate the extent to which a society pollutes per inhabitant. While these atmospheric pollutants are not necessarily all pollutants harmful to all aspects of the natural environment, they do capture the intensity of harm caused in terms of climate-altering environmental change (Farzin and Bond, 2006).

Our main independent variable is the VDEM's measure of "egalitarian democracy."

According to the VDEM researchers, an egalitarian democracy builds on the theorized notion that individuals from all social groups ought to be equally capable of exercising their political rights and freedoms, and of influencing political and governing processes. Underlying this broad principle are two main sub-components: equal protection and equal distribution of resources and income protection. Equal protection implies that the state grants and protects rights and freedoms evenly across social groups (Sigman and Lindberg, 2019). According to them, "an equal distribution of resources ensures that individuals have the basic necessities enabling them to exercise those rights and freedoms, leading towards an equal potential to influence decision making" (Sigman and Lindberg 2015: 1). An egalitarian democracy must also assure equal access to political power for all social groups, so that there is inclusivity in political decision making. They argue further that greater egalitarian processes make the democratic polity more effective. Equality among groups would produce lower levels of polarization and greater egalitarian democratic processes would resolve political and policy disputes more effectively than less egalitarian democratic processes (Sigman and Lindberg, 2015). Thus, VDEM's egalitarian democracy measurement includes several indicators capturing equal access to power, political resources, liberties and political inclusion, plus the degree of electoral democracy, or polyarchy, indicated by free and fair elections without coercion or violence in a competitive processes (VDEM, 2019). These data are generated by a number of country, regional and subjectbased experts, and the coding is subject to rigorous reliability tests, such as item response theory, which generates a single value for each state after minimizing coding bias (Sigman and Lindberg, 2019).

Naturally, we include several control variables, but keep these limited in our basic model in order not to overfit our models (Achen, 2005). Naturally, democracy relates to the level of income in a society and income may matter independently for sustainable development and the amount of $\mathrm{CO} 2$ and GHGs produced on a per capita basis (Hess, 2010). We add GDP per capita in constant $2010 \$$ taken from the WDI, which we log in order to reduce skewness for avoiding bias from the effects of extreme values. Next, we add two separate demographic variables, which are 
the log of the share of the population urban and the log of population density because these factors relate directly to measures of sustainability and atmospheric pollution and relate to the nature of egalitarian democracy (Hess, 2010). (Note 5) To this basic model, we add several other variables gleaned from the literature (Hess, 2010; de Soysa et al., 2009). We begin with adding indicators of political stability measured as armed conflict where at least 25 battle-related deaths have occurred in a single year plus the years of peace since any such conflict might have ended, starting the count in 1946 or the year of independent statehood. (Note 6) In these robustness tests, we add, one by one, the level of political corruption taken from the VDEM dataset, age dependency ratio, natural resource rents per GDP, and international trade per GDP, all of which relate to some degree with $\mathrm{x}$ and the $\mathrm{y}$ variable. (Note 7)

Our dataset is a time-series, cross-sectional (TSCS) dataset covering roughly 170 countries from 1970 onwards annually (the ANS data are available from 1990 onwards). The dataset is unbalanced meaning that not all countries have the same years of coverage. The analysis of TSCS data present some complications for standard regression because of the complicated correlation patterns between and across cases within the panels. The first issue is bias from temporal dependence (autocorrelation), where the error term correlates across the panels over time. Autocorrelation can inflate standard errors leading to biased results. Secondly, there could be spatial dependence, where the units (countries) correlate with each other across space systematically. Given the spatial clustering nature of policies, whether from the point of view of the independent or the dependent variables, accounting for this spatial autocorrelation is important for estimating unbiased results. Driscoll and Kraay develop a method for estimating standard errors robust to spatial correlation using ordinary least squares (OLS) regression (Driscoll and Kraay, 1998; Hoechle, 2007). This method also allows one to estimate fixed effects, or examine the within-unit variance, and estimate an AR1 process for accounting for first-order serial correlation. (Note 8) We estimate all our $\mathrm{x}$ variables lagged by 1 year to avoid simultaneity. We include year-fixed effects to avoid any bias from simultaneously trending data. Summary statistics of each of the variables are in the appendix.

\section{Results}

Table 1 presents results of regressions of the effects of egalitarian democracy on two weak sustainability measures; namely, the net national savings as a share of GDP and $\mathrm{CO}_{2}$ emissions as a share of GDP.

Table 1 . The effect of egalitarian democracy on weak sustainability

(1) (2)

\begin{tabular}{lcc} 
Dependent variables & ANS/GDP & CO2/GDP \\
\hline & & \\
Egalitarian democracy & $-9.269^{* *}$ & $0.308^{* * *}$ \\
& $(3.827)$ & $(0.0610)$ \\
Income per capita (ln) & $9.550^{* * *}$ & $-0.218^{* * *}$ \\
& $(1.765)$ & $(0.0235)$ \\
Urban population\% (ln) & -5.177 & $0.770^{* * *}$ \\
& $(3.529)$ & $(0.0586)$ \\
Population density $(\ln )$ & 5.685 & $0.624 * * *$ \\
& $(3.790)$ & $(0.0668)$ \\
Constant & 0 & $-4.215^{* * *}$ \\
& $(0)$ & $(0.298)$ \\
Observations & 3,429 & 6,354 \\
Number of countries & 153 & 168 \\
\hline
\end{tabular}

Driscoll-Kraay standard errors in parentheses

${ }^{* * *} \mathrm{p}<0.01,{ }^{* *} \mathrm{p}<0.05,{ }^{*} \mathrm{p}<0.10$

All $\mathrm{x}$ variables lagged 1 year 
As seen in column 1, when we estimate sustainability based on the adjusted net savings, egalitarian democracy is negative and statistically highly significant, independent of each of the controls in the model. Substantively, a standard deviation (within) increase in egalitarian democracy reduces adjusted net savings (ANS) by roughly 7\% of the within standard deviation of ANS. Comparatively, increasing per capita income by a similar amount increases ANS by $28 \%$ of a standard deviation of ANS. While democracy's negative effect is comparatively small substantively, the direct effect of democracy, especially egalitarian democracy, is negative, a result supporting previous studies that have used other measures of democracy, such as the POLITY index (de Soysa et al., 2009). In column 2, when we test our second weak sustainability measure, or $\mathrm{CO}_{2}$ damage per GDP, egalitarian democracy is positive and statistically highly significant, meaning that higher egalitarian democracy increases $\mathrm{CO}_{2}$ pollution per unit of production. Substantively, a standard deviation increase in EDEM increases atmospheric pollution per GDP by roughly $6 \%$ of a standard deviation of $\mathrm{CO}_{2} / \mathrm{GDP}$. Comparatively, a similar increase in income per capita reduces $\mathrm{CO}_{2}$ pollution intensity per GDP by roughly $15 \%$ of a standard deviation in pollution intensity. In summary, total savings, including human capital accumulation is greater when countries become wealthier, and wealth increases the environmental efficiency of wealth creation, but egalitarian democracy shows the opposite effect.

In Table 2, we test our two pure measures of strong sustainability, namely total greenhouse gas emissions per capita $(\mathrm{GHGe} / \mathrm{pc})$ and $\mathrm{CO}_{2}$ emissions (metric tons) per capita $\left(\mathrm{CO}_{2} \mathrm{emt} / \mathrm{pc}\right)$. Now the question of environmental degradation relative to wealth creation criteria does not enter the picture.

Table 2. The effects of egalitarian democracy on strong sustainability

\begin{tabular}{lcc}
\hline & $(1)$ & $(2)$ \\
Dependent variables & $\mathrm{CO} 2 / \mathrm{pc}$ & $\mathrm{GHG} / \mathrm{pc}$ \\
\hline & $0.378^{* * *}$ & $0.199^{* * *}$ \\
Egalitarian democracy & $(0.0378)$ & $(0.0434)$ \\
& $0.766^{* * *}$ & $0.424^{* * *}$ \\
Income per capita $(\ln )$ & $(0.0207)$ & $(0.0243)$ \\
& $0.461^{* * *}$ & $0.205^{* * *}$ \\
Urban population\% $(\mathrm{ln})$ & $(0.0560)$ & $(0.0618)$ \\
& $0.383^{* * *}$ & 0.0789 \\
Population density $(\ln )$ & $(0.0291)$ & $(0.0656)$ \\
& $-8.939 * * *$ & 0 \\
Constant & $(0.285)$ & $(0)$ \\
& 6,072 & 5,600 \\
Observations & 169 & 166 \\
Number of countries & & \\
\hline Driscoll-Kraay standard errors in parentheses & & \\
$* * * \mathrm{p}<0.01, * * \mathrm{p}<0.05, * \mathrm{p}<0.10$ & & \\
All $\mathrm{x}$ variables lagged 1 year & & \\
Year fixed effects estimated & &
\end{tabular}

In column 1, we test $\mathrm{CO}_{2}$ emissions per person. Again egalitarian democracy shows positive and statistically highly significant effect, which is replicated in column 2 when total greenhouse gases per capita is tested. Substantively, a within standard deviation increase in egalitarian democracy increases per capita $\mathrm{CO}_{2}$ emissions by $9 \%$ of a within standard deviation of $\mathrm{CO}_{2}$ emissions. Similarly, raising egalitarian democracy by a standard deviation within could raise GHGs per capita by roughly $6 \%$ of a within standard deviation of GHG emissions per capita. Notice that this time, income per capita increases both $\mathrm{CO} 2$ per capita and total GHGs per capita. While richer countries are more environmentally efficient at producing wealth, they create greater pollution per person into the atmosphere, presumably due to higher consumption. Substantively, increasing income per capita by a standard deviation increases total $\mathrm{GHGe} / \mathrm{pc}$ by roughly $38 \%$ of a standard deviation in $\mathrm{GHGe} / \mathrm{pc}$, which is comparatively very large. 
Given the intense focus on the "Environmental Kuznets' Curve" (EKC), which suggests that increasing wealth increases pollution at first, but that it reduces at higher levels of income to form an inverted-U-shaped relationship with pollution. We tested this parabolic curve by squaring per capita income (not shown). We found that the effect is linear, where total GHGe/pc is highest at the highest levels of income, results consistent with others that do not find evidence for the EKC (Sirag et al., 2018). Thus, results on egalitarian democracy and income per capita on strong sustainability indicators measured as $\mathrm{CO}_{2}$ and GHG emissions per capita suggest that egalitarian governance and income per capita independently produce more atmospheric. This result obtains despite the fact that the two outcome variables are correlated only at $r=0.62$, which is moderate. Again, we find no evidence for an EKC. Wealthier countries pollute more on two counts - their wealth has a direct effect on emissions and their "politics" seem to spur greater pollution, not less, especially when assessed with strong sustainability measures.

Next, we test our basic model including conditional terms of egalitarian democracy and a dummy variable capturing the old, industrialized democracies, that have an advantage in terms of technology and cooperation on standards, while also having had the luxury historically of having developed strong egalitarian institutions. Thus, egalitarian democracy might work best among this group of nations compared with the rest. Results from interaction terms are unbiased in fixed effects regressions when at least one of the terms is time invariant (Collischon and Eberl, 2020). (Note 9) As seen in Table 3, columns 1 \& 2,

Table 3. The conditional effects of egalitarian democracy and industrialized countries on adjusted net savings and $\mathrm{CO}_{2}$ emissions per capita

(1)

Dependent variable

Egalitarian democracy

Industrialized Countries

Egalitarian democrac $\mathrm{x}$ industialized Countries

Income per capita $(\ln )$

Urban population \% (ln)

Populations density $(\ln )$

Constant

Observations

R-squared

Number of groups
ANS/GDP

$-9.408 * *$

5.310

$9.553^{* * *}$

$-86.75^{* *}$

3,429

0.740

153
(2)

$\mathrm{CO} 2 / \mathrm{pc}$

$0.766^{* * *}$

$0.459 * * *$

$0.379 * * *$

$-10.32^{* * *}$

6,072

0.979

169

Driscoll-Kraay standard errors in parentheses

$* * * \mathrm{p}<0.01, * * \mathrm{p}<0.05, * \mathrm{p}<0.10$

All $x$ variables lagged 1 year

Two-way fixed effects estimated

Egalitarian democracy $\mathrm{x}$ industrialized countries are statistically not significant. Notice that egalitarian democracies when industrialized countries are 0 , shows statistically significant negative effects on sustainability and atmospheric pollution. The basic picture from the conditional effects, however, is that there is no special 
environmental effect of egalitarian governments among the industrialized democracies argued to be occurring due to post-material values (Granato et al., 1996; Inglehart and Welzel, 2005).

Next, we vary our basic model by adding several other variables that are potential confounders, such as natural resource wealth, trade dependence, the age-dependency ratio and political instability. First, however, we drop the old, industrialized democracies from the sample. Running the results in Table 1 with only "developing countries" reproduces results almost identically, except that now total greenhouse gas emissions is not statistically significant. The basic pattern of income per capita, or the level of development, increasing weak sustainability but harming strong sustainability is retained. Next, we enter the conflict variables, ongoing civil war and the years of peace. The basic results on egalitarian democracy hold. These results hold when entering the measure of trade openness, which is positive for ANS but increases emissions. They also hold when entering the natural resource wealth variable, which is only weakly related to the dependent variables, but the sign is in the expected direction. Neither entering age-dependency nor political corruption made little difference to the basic results on egalitarian democracy as displayed in Table $1 \& 2$. These results, thus, are robust to estimating procedure, sample sizes, varying models, and varying conceptualization and measurement of sustainability.

Finally, we address the question of equity on sustainability by parsing out the effects of democracy from inequality. Since egalitarian democracy captures both political inclusivity and other egalitarian dimensions in terms of equal access to public goods and political resources, we now strip away the political inclusion and test both income inequality measured by the GINI and equality of access to human capital resources on our measures of sustainability. (Note 10) We hold constant democracy in the model using the VDEM's polyarchy measure, which is focused only on free and fair elections and is a minimum definition of democracy. We test the effects of the GINI and VDEM's measure of equality of access to health on our two weak sustainability outcomes (ANS \& $\left.\mathrm{CO}_{2} / \mathrm{GDP}\right)$. As seen in Table 4, column 1 and 2,

Table 4. The effect of income inequality (GINI) on sustainability \& $\mathrm{CO}_{2}$ emissions

\begin{tabular}{lcc}
\hline & $(1)$ & $(2)$ \\
Dependent variable & ANS/GDP & CO2/pc \\
\hline \multirow{2}{*}{ GINI } & -0.0450 & $-0.0145^{* * *}$ \\
& $(0.120)$ & $(0.00265)$ \\
Electoral democracy & $-7.411^{* *}$ & $0.107^{* * *}$ \\
& $(3.171)$ & $(0.0225)$ \\
Income per capita (ln) & $9.339^{* * *}$ & $0.756^{* * *}$ \\
& $(1.936)$ & $(0.0260)$ \\
Urban population \% (ln) & $-7.194^{*}$ & $0.593^{* * *}$ \\
& $(3.891)$ & $(0.0559)$ \\
Population density $(\ln )$ & 0.453 & $0.362^{* * *}$ \\
& $(1.762)$ & $(0.0547)$ \\
Constant & $-39.74 * *$ & $-8.581^{* * *}$ \\
& $(15.51)$ & $(0.356)$ \\
Observations & 2,949 & 4,209 \\
Number of countries & 151 & 166 \\
\hline Driscoll-Kraay standard errors in parentheses & \\
$* * * \mathrm{p}<0.01, * * \mathrm{p}<0.05, * \mathrm{p}<0.10$ & & \\
All $\mathrm{x}$ variables lagged 1 year & &
\end{tabular}

The GINI has no statistically significant effect on ANS, but it lowers CO2 emissions per GDP in column 2. These results support others that have used different data to argue that inequality reduces environmental harm (Scruggs, 
1998). Substantively, a standard deviation (within) increase in the GINI reduces $\mathrm{CO}_{2}$ per GDP produced by $10 \%$ of a standard deviation (within) of $\mathrm{CO}_{2}$ per GDP. In Table 5, when we estimate equality of access to health,

Table 5. Effects of health equality on sustainability and $\mathrm{CO}_{2}$ pollution

\begin{tabular}{lcc}
\hline & $(1)$ & $(2)$ \\
Dependent variable & ANS/GDP & CO2/pc \\
\hline & 0.437 & $0.0628^{* * *}$ \\
Equality of health (access) & $(0.455)$ & $(0.00797)$ \\
Electoral democracy & $-5.686^{*}$ & $0.215^{* * *}$ \\
& $(3.309)$ & $(0.0268)$ \\
Income per capita $(\ln )$ & $9.331^{* * *}$ & $0.757^{* * *}$ \\
& $(1.836)$ & $(0.0207)$ \\
Urban population \% $(\ln )$ & -4.862 & $0.466^{* * *}$ \\
& $(3.535)$ & $(0.0578)$ \\
Population density $(\ln )$ & 5.718 & $0.358^{* * *}$ \\
& $(3.781)$ & $(0.0286)$ \\
Constant & 0 & $-8.775^{* * *}$ \\
& $(0)$ & $(0.275)$ \\
Observations & 3,429 & 6,072 \\
Number of countries & 153 & 169 \\
\hline Driscoll-Kraay standard errors in parentheses & \\
$* * *$ p $<0.01, * * \mathrm{p}<0.05, * \mathrm{p}<0.10$ & & \\
All x variables lagged 1 year & & \\
Two-way fixed effects & &
\end{tabular}

The results remain pretty much the same. Greater equality increases environmental harm, at least in terms of per capita $\mathrm{CO}_{2}$ emissions. Notice from both tables that democracy seems to hurt both weak and strong sustainability, consistently and robustly. Taking all of the results discussed above, there is overwhelming evidence against accepting the hypothesis that greater egalitarian democracy and process of equity captured in the GINI and as access to public goods increase demands for more environmentally-friendly outcomes. It seems that achieving weak and strong sustainability may require more targeted policies rather than simple prescriptions about getting the "politics of redistribution" right. While reducing societal disparities between rich and poor and other social groupings is intrinsically good and moral, there does not seem to be any cause to hope that the environment too will benefit. Indeed, the evidence suggests rather that processes driving equality might also be encouraging some environmental destruction, both directly and indirectly through consumption.

\section{Conclusion}

Addressing global poverty and inequality and achieving sustainable development in terms of transiting to a low carbon future are urgent policy challenges (Stern, 2015). Many, especially critics of neoliberal globalization, suggest that discontent with regular politics addressing the vexing issue of reducing greenhouse gas emissions and getting to the $2^{\circ} \mathrm{C}$ target by century's end arises from deep suspicions of elite-led politics (Stiglitz, 2019a; Rodrik, 2011). Greater egalitarian processes around politics and economy, they argue, also build the legitimacy and support for the hard choices required for dealing with climate change and other environmental crises (Wilkinson and Pickett, 2009). Others are more skeptical about the prospects of the ability of people, whatever the legitimacy with which political institutions are viewed, for making informed decisions about policy, especially on complex subjects such as environmental issues (Achen and Bartels, 2017). We address the issue using novel data on egalitarian democracy. Our findings simply do not support the argument that greater inclusivity increases the prospects of reducing climate-affecting pollution. In fact, the opposite seems to be true, both in terms of reducing weak 
sustainability and damaging the climate, results reported also by several others that have addressed the effects of democracy and of egalitarian processes on environmental outcomes. Equality, democracy, and higher incomes are societal "goods" in and of themselves, but the results obtained here suggest that they reduce the chances of producing wealth more environmentally efficiently and encourages higher pollution. The French revolutionary slogan of "liberté, égalité, fraternité does not unfortunately seem also to promote better environmental outcomes, but then again, such slogans were invented to spur production and consumption and man's domination over nature in the name of progress and material salvation. Future research might probe how economic freedoms, rather than political ones, generate conditions conducive to favorable environmental outcomes, or the power of free markets over planning where market choices may trump democratic ones for driving environmental change.

\section{Acknowledgement}

We would like to thank the editor and an anonymous reviewer for comments and suggestions. The insightful feedback from Giovanni Millo and John Oneal are gratefully acknowledged. All shortcomings must be blamed only on us.

\section{References}

Acemoglu, D., \& Robinson, J. (2012). Why Nations Fail: The Origins of Power, Prosperity and Poverty. New York: Crown Publishers. https://doi.org/10.1355/ae29-2j

Achen, C., Bartels, L. M. (2017). Democracy for Realists: Why Elections Do Not Produce Responsive Government. Princeton, NJ: Princeton University Press. https://doi.org/10.2307/j.ctvc7770q

Achen, C. H. (2005). Let's Put the Garbage-Can Regressions and Garbage-Can Probits Where They Belong. Conflict Management and Peace Science, 22, 327-339. https://doi.org/10.1080/07388940500339167

Atkinson, G., Dietz, S., \& Neumayer, E. (2007). Introduction. In Atkinson G., Dietz S., \& Neumayer E. (Eds.), Handbook of Sustainable Development (pp. 1-23). Cheltenham: Edward Elgar. https://doi.org/10.4337/9781847205223

Atkinson, G. et al. (1999). Measuring Sustainable Development: Macroeconomics and the Environment. Cheltanham: Edward Elgar.

Bell, K. (2014). Achieving Environmental Justice: A Cross-national Analysis. Bristol: Bristol University Press. https://doi.org/10.2307/j.ctt9qgzvd

Bernauer, T., \& Kouby, V. (2009). Effects of Political Institutions on Air Quality. Ecological Economics, 68(5), 1355-1365. https://doi.org/10.1016/j.ecolecon.2008.09.003

Caplan, B. (2008). The Myth of the Rational Voter: How Democracies Choose Bad Policies. Princeton, NJ: Princeton University Press. https://doi.org/10.1515/9781400828821

Christoff, P., \& Eckersley, R. (2011). Comparing State Responses. In Dryzek J. S., Norgaard R. B., \& Schlosberg D. (Eds.), Oxford Handbook of Climate Change and Society (pp. 431-448). Oxford: Oxford University Press.

Clement, M., \& Meunie, A. (2010). Is Inequality Harmful for the Environment? An Empirical Analysis Applied to Developing and Transition Countries. Review of Social Economy, 68(4), 413-445. https://doi.org/10.1080/00346760903480590

Collier, P. (2010). The Political Economy of Natural Resources. Social Research, 77(4), 1105-1132.

Collier, P. (2018). The Future of Capitalism: Facing the New Anxieties. New York: HarperCollins.

Collischon, M., \& Eberl, A. (2020). Let's talk About Fixed Effects: Let's Talk About All the Good Things and the Bad Things. KZfSS Kölner Zeitschrift für Soziologie und Sozialpsychologie, 72, 289-299. https://doi.org/10.1007/s11577-020-00699-8

Conca, K., \& Dabelko, J. D. (1998). Green Planet Blues: Environmental Politics from Stockholm to Kyoto (2nd ed.). Boulder, CO: Westview.

Congleton, R. D. (2002). Political Institutions and Pollution Control. Review of Economics and Statistics, 74(3), 412-421. https://doi.org/10.2307/2109485

de Soysa, I., Bailey, J., \& Neumayer, E. (2009). Free to Squander? Democracy and Economic Sustainability, 19802001. In Matthew R. A. et al. (Eds.), Global Environmental Change and Human Security. Cambridge, MA: MIT Press. 
de Soysa, I., \& Neumayer, E. (2005). False Prophet, or Genuine Savior? Assessing the Effects of Economic Openness on Sustainable Development, 1980-1999. International Organization, 59(3), 731-772. https://doi.org/10.1017/S0020818305050253

Deaton, A., \& Case, A. (2020). Rebottling the Gini: Why this Headline Measure of Inequality Misses Everything that Matters. Prospect. Retrieved March 5, 2020, from https://www.prospectmagazine.co.uk/economics-andfinance/rebottling-the-gini-why-this-headline-measure-of-inequality-misses-everything-that-matters

Dietz, S., Neumayer, E., \& de Soysa, I. (2007). Corruption, the Resource Curse and Genuine Savings. Environment and Development Economics, 12(1), 33-53. https://doi.org/10.1017/S1355770X06003378

Dollar, D., \& Collier, P. (2001). Globalization, Growth and Poverty: Building an Inclusive World Economy. Oxford: Oxford University Press.

Driscoll, J. C., \& Kraay, A. C. (1998). Consistent Covariance Matrix Estimation with Spatially Dependent Panel Data. Review of Economics and Statistics, 80(4), 549-560. https://doi.org/10.1162/003465398557825

Drukker, D. M. (2003). Testing for Serial Correlation in Linear Panel-data Models. The Stata Journal, 3(2), 168177. https://doi.org/10.1177/1536867X0300300206

Dryzek, J. S. (1997). Environmental Discourses: The Politics of the Earth. Oxford: Oxford University Press.

Dryzek, J. S., Norgaard, R. B., \& Schlosberg, D. (2011). Climate Change and Society: Approaches and Responses. In Dryzek J. S., Norgaard R. B., \& Schlosberg D. (Eds.), Oxford Handbook of Climate Change and Society (pp. 3-17). Oxford: Oxford University Press. https://doi.org/10.1093/oxfordhb/9780199566600.003.0001

Farzin, H. Y., \& Bond, C. A. (2006). Democracy and Environmental Quality. Journal of Development Economics, 81, 213-235. https://doi.org/10.1016/j.jdeveco.2005.04.003

Galbraith, J. K. (2019). The Next Great Transformation. Project Syndicate (November 08 issue). Retrieved from https://www.project-syndicate.org/onpoint/the-next-great-transformation-by-james-k-galbraith-201911 ?barrier=accesspaylog

Granato, J., Inglehart, R., \& Leblang, D. (1996). The Effects of Cultural Values on Economic Development: Theory, Hypotheses, and Some Empirical Tests. American Journal of Political Science, 40(3), 607-631. https://doi.org/10.2307/2111786

Griggs, D., et al. (2013). Sustainable Development Goals for People and Planet. Nature, 495(March), 305-307. https://doi.org/10.1038/495305a

Hamilton, K. (2000). Genuine Savings as a Sustainability Indicator. Retrieved from http://www.uea.ac.uk/env/cserge/pub/wp/gec/gec_1997_03.pdf

Hamilton, K., \& Ruta, G. (2009). Wealth Accounting, Exhaustible Resources and Social Welfare. Environmental and Resource Economics, 42(1), 53-64. https://doi.org/10.1007/s10640-008-9235-7

Hardin, G. (1993). Living Within Limits: Ecology, Economics and Population Taboos. New York: Oxford University Press.

Harvey, F. (2019). Richer Nations Accused of Stalling Progress on Climate Crisis. The Guardian, Saturday, 14 December.

Hess, P. (2010). Determinants of the Adjusted Net Saving Rate in Developing Economies. International Review of Applied Economics, 24(5), 591-608. https://doi.org/10.1080/02692170903426070

Hoechle, D. (2007). Robust Standard Errors for Panel Regressions with Cross-Sectional Dependence. The Stata Journal, 7, 281-312. https://doi.org/10.1177\%2F1536867X0700700301

Inglehart, R., \& Norris, P. (2016). Trump, Brexit, and the Rise of Populism: Economic Have-Nots and Cultural Backlash. HKS working paper no. 16-026 Retrieved from https://papers.ssrn.com/sol3/papers.cfm?abstract_id=2818659

Inglehart, R., \& Welzel, C. (2005). Modernization, Cultural Change, and Democracy: The Human Development Sequence. Cambridge: Cambridge University Press.

Jamieson, D. (2011). The Nature of the Problem. In Dryzek J. S., Norgaard R. B., \& Schlosberg D. (Eds.), Oxford Handbook of Climate Change and Society (pp. 38-54). Oxford: Oxford University Press.

Jordan, A., Wurzel, R. K. W., \& Zito, A. R. (2003). 'New' Instruments of Environmental Governance? National Experiences and Prospects. London: Frank Cass. https://doi.org/10.4324/9780203010396 
Lafferty, W. M., \& Meadowcroft, J. (1996). Democracy and the Environment: Problems and Prospects. Cheltenham: Edward Elgar.

Li, Q., \& Reuveny, R. (2006). Democracy and Environmental Degradation. International Studies Quarterly, 50, 935-956. https://doi.org/10.1111/j.1468-2478.2006.00432.x

Midlarsky, M. I. (2001). Democracy and the Environment. In Diehl P. F., \& Gleditsch N. P. (Eds.), Environmental Conflict (pp. 155-178). Boulder, CO: Westview.

Milanovic, B. (2016). Global Inequality: A New Approach for the Age of Globalization. Cambridge, MA: Belknap. https://doi.org/10.4159/9780674969797

Niemeyer, S. (2013). Democracy and Climate Change: What Can Deliberative Democracy Contribute? Australian Journal of Politics and History, 59(3), 429-448. https://doi.org/10.1111/ajph.12025

North, D. C., Wallis, J. J., \& Weingast, B. R. (2013). Violence and Social Orders: A Conceptual Framework for Interpreting Recorded Human History. Cambridge: Cambridge University Press.

OECD OfECaD. (2015). In it Together: Why Less Inequality Benefits All. Paris: Organization for Economic Cooperation and Development (OECD).

Ostrom, E. (2005). Understanding Institutional Diversity. Princeton, NJ: Princeton University Press.

Pearce, D., \& Atkinson, G. (1993). Capital Theory and the Measure of Sustainable Development: An Indicator of Weak Sustainability. Ecological Economics, 3(103-108). https://doi.org/10.1016/0921-8009(93)90039-9

Peluso, N. L. (2003). Coercing Conservation. In Conca K., \& Dabelko G. D. (Eds.), Green Planet Blues: Environmental Politics from Stockholm to Johannesburg (pp. 346-357). Boulder, CO: Westview.

Pettersson, T., \& Eck, K. (2018). Organized Violence, 1989-2017. Journal of Peace Research, 55(4), 535-547. https://doi.org/10.1177\%2F0022343318784101

Qasim, M., \& Grimes, A. (2018). Sustainable Economic Policy and Well-being: The Relationship Between Adjusted Net Savings and Subjective Well-Being. Reportno. Report Number|, Date. Place Published|: Institution|. https://doi.org/10.2139/ssrn.3187101

Rodrik, D. (2011). The Globalization Paradox: Why Global Markets, States, and Democracy Can't Coexist. Oxford: Oxford University Press.

Schreurs, M. (2011). Climate Change Politics in an Authrotarian State: The Ambivalent Case of China. In Dryzek J. S., Norgaard R. B., \& Schlosberg D. (Eds.), Oxford Handbook of Climate Change and Society (pp. 449463). Oxford: Oxford University Press.

Schumpeter, J. A. (1943). Capitalism, Socialism and Democracy. London: Allen and Unwin.

Scruggs, L. (1998). Political and Economic Inequality and the Environment. Ecological Economics, 26(3), 259275. https://doi.org/10.1016/S0921-8009(97)00118-3

Sigman, R., \& Lindberg, S. (2015). The Index of Egalitarian Democracy and Its Components: V-Dem's Conceptualization and Measurement. Reportno. Report Number|, Date. Place Published|: Institution|. https://doi.org/10.2139/ssrn.2727612

Sigman, R., \& Lindberg, S. (2019). Democracy for All: Conceptualizing and Measuring Egalitarian Democracy. Political Science Research and Methods, 7(3), 595-612. https://doi.org/10.1017/psrm.2018.6

Sirag, A., et al. (2018). Does Environmental Kuznets Curve Hypothesis Exist? Evidence from Dynamic Panel Threshold. Journal of Environmental Economics and Policy, 7(2), 145-165. https://doi.org/10.1080/21606544.2017.1382395

Solt, F. (2019). Measuring Income Inequality Across Countries and Over Time: The Standardized World Income Inequality Database. Reportno. Report Number|, Date. Place Published|: Institution|. https://doi.org/10.31235/osf.io/mwnje

Steffen, W. (2011). A Truly complex and Diabolical Policy Problem. In Dryzek J. S., Norgaard R. B., \& Schlosberg D. (Eds.), Oxford Handbook of Climate Change and Society (pp. 21-37). Oxford: Oxford University Press. https://doi.org/10.1093/oxfordhb/9780199566600.003.0002

Stern, N. (2015). Why Are We Waiting? The Logic, Urgency, and Promise of Tackling Climate Change. London: The MIT Press. 
Stewart, F., Brown, G., \& Mancini, L. (2005). Why Horizontal Inequalities Matter: Some Implications for Measurement. Reportno. Report Number|, Date. Place Published|: Institution|.

Stiglitz, J. E. (2019a). People, Power, and Profits: Progressive Capitalism for an Age of Discontent. New York: W.W. Norton \& Co.

Stiglitz, J. E. (2019b). The End of Neoliberalism and the Rebirth of History. Project Syndicate (November 04 issue). Retrieved from https://www.project-syndicate.org/commentary/end-of-neoliberalism-unfetteredmarkets-fail-by-joseph-e-stiglitz-2019-11?barrier=accesspaylog

UNEP. (2019). Emissions Gap Report: Executive Summary. Reportno. Report Number|, Date. Place Published|: Institution|.

VDEM voDP. (2019). Varieties of Democracy, Codebook. Reportno. Report Number|, Date. Place Published|: Institution|.

Ward, H. (2008). Liberal democracy and sustainability. Environmental Politics, 17(3), 386-489. https://doi.org/10.1080/09644010802055626

WCED WCoEaD. (1987). Our Common Future. Oxford: Oxford University Press.

Wenar, L. (2016). Blood Oil: Tyrants, Violence, and the Rules that Run the World. Oxford: Oxford University Press.

Wilkinson, R., \& Pickett, K. (2009). The Spirit Level: Why More Equal Societies Almost Always Do Better. London: Allen Lane.

Worland, J. (2019). Donald Trump Called Climate Change a Hoax. Now He's Awkwardly Boasting About Fighting It. Time. Retrieved from https:/time.com/5622374/donald-trump-climate-change-hoax-event/

World Bank. (2020). The World Development Indicators online database. Retrieved from https://databank.worldbank.org/reports.aspx? source=world-development-indicators\&preview $=$ on\#

Wurster, S. (2013). Comparing Ecological Sustainability in Autocracies and Democracies. Contemporary Politics, 19(1), 76-93. https://doi.org/10.1080/13569775.2013.773204

\section{Notes}

Note 1. Stiglitz and others who argue that populists are created by mass discontent fail to explain how people raging against inequality and environmental harm vote for a billionaire offering tax cuts for the rich, promising to roll back environmental regulation.

Note 2. The construction of this measure is described in detail below.

Note 3. See https://databank.worldbank.org/reports.aspx? source=world-development-indicators\&preview $=$ on\# (last accessed March 06, 2020).

Note 4. For a detailed, economic theory based rationale for the accounting methods, see Hamilton $\mathrm{K}$ and Ruta $\mathrm{G}$ (2009) Wealth Accounting, Exhaustible Resources and Social Welfare. Environmental and Resource Economics 42(1): 53-64.

Note 5. Both variables are taken from the WDI.

Note 6. These data are taken from the Uppsala Conflict Data Project (UCDP). See Pettersson T and Eck K (2018) Organized Violence, 1989-2017. Journal of Peace Research 55(4): 535-547.

Note 7. The age-dependency ratio, trade/ GDP, and natural resource rents / GDP are taken from the WDI.

Note 8. We estimate the Wooldridge test on our data and could not reject the null hypothesis of no first order serial correlation Drukker DM (2003) Testing for Serial Correlation in Linear Panel-data Models. The Stata Journal 3(2): 168-177.

Note 9. The old industrial democracies are Western European countries, North America, Oceania, and Japan.

Note 10. We use the standardized income inequality data (SWIID) that use the Luxembourg household income studies to standardize GINIs based on national accounts and other sources. For a detailed description, see Solt F (2019) Measuring Income Inequality Across Countries and Over Time: The Standardized World Income Inequality Database. Reportno. Report Number|, Date. Place Published|: Institution|. 


\section{Copyrights}

Copyright for this article is retained by the author(s), with first publication rights granted to the journal.

This is an open-access article distributed under the terms and conditions of the Creative Commons Attribution license (http://creativecommons.org/licenses/by/4.0/). 